\title{
MOCVD ZnO/Screen Printed Ag Back Reflector for Flexible Thin Film Silicon Solar Cell Application
}

\author{
Amornrat Limmanee, Patipan Krudtad, Sasiwimon Songtrai, Suttinan Jaroensathainchok, \\ Taweewat Krajangsang, Jaran Sritharathikhun, and Kobsak Sriprapha
}

\author{
Solar Energy Technology Laboratory, National Electronics and Computer Technology Center (NECTEC), \\ National Science and Technology Development Agency, 112 Thailand Science Park, Phahonyothin Road, Klong 1, Klong Luang, \\ Pathumthani 12120, Thailand
}

Correspondence should be addressed to Amornrat Limmanee; amornrat.limmanee@nectec.or.th

Received 8 May 2013; Accepted 17 December 2013; Published 23 January 2014

Academic Editor: Jun-Ho Yum

Copyright (C) 2014 Amornrat Limmanee et al. This is an open access article distributed under the Creative Commons Attribution License, which permits unrestricted use, distribution, and reproduction in any medium, provided the original work is properly cited.

\begin{abstract}
We have prepared Ag back electrode by screen printing technique and developed MOCVD ZnO/screen printed Ag back reflector for flexible thin film silicon solar cell application. A discontinuity and poor contact interface between the MOCVD ZnO and screen printed Ag layers caused poor open circuit voltage $\left(V_{\mathrm{oc}}\right)$ and low fill factor $(\mathrm{FF})$; however, an insertion of a thin sputtered $\mathrm{ZnO}$ layer at the interface could solve this problem. The $\mathrm{n}$ type hydrogenated amorphous silicon (a-Si:H) film is preferable for the deposition on the surface of MOCVD ZnO film rather than the microcrystalline film due to its less sensitivity to textured surface, and this allowed an improvement in the FF. The n-i-p flexible amorphous silicon solar cell using the MOCVD $\mathrm{ZnO} / \mathrm{screen}$ printed Ag back reflector showed an initial efficiency of $6.2 \%$ with $V_{\mathrm{oc}}=0.86 \mathrm{~V}, J_{\mathrm{sc}}=12.4 \mathrm{~mA} / \mathrm{cm}^{2}$, and $\mathrm{FF}=0.58\left(1 \mathrm{~cm}^{2}\right)$. The identical quantum efficiency and comparable performance to the cells using conventional sputtered Ag back electrode have verified the potential of the MOCVD $\mathrm{ZnO} /$ screen printed Ag back reflector and possible opportunity to use the screen printed Ag thick film for flexible thin film silicon solar cells.
\end{abstract}

\section{Introduction}

Researches regarding silicon solar cells prepared on flexible substrates such as polymer and stainless steel using n-i-p structure are of interest and have been intensively developed by many research groups [1-6]. For an efficient light trapping in the n-i-p configuration, the textured back reflector scattering the light backward, which results in an increase in light path in the absorber layer, is verified to be an effective technique to enhance short circuit current density $\left(J_{\mathrm{sc}}\right)$ of the cells [7]. Our group has reported potential of the zinc oxide $(\mathrm{ZnO})$ films with naturally grown textured surface by metalorganic chemical vapor deposition (MOCVD) technique as a back reflector of the n-i-p flexible solar cells [8]. Enhancements in the $J_{\mathrm{sc}}$ and the quantum efficiency results of the cells have verified high-efficient performance of the MOCVD $\mathrm{ZnO} /$ sputtered Ag back reflector. Since there is no need of an additional process to modify the surface of $\mathrm{ZnO}$ films, this back reflector has advantages of reducing process time and production cost.
Besides sputtering technique, there are several techniques that can be used to prepare metal electrodes such as evaporation, ion-plating, and screen printing. Printing techniques are regarded as solutions to remove costly and complicated methods such as photolithography and high vacuum processes. Screen printing method of metal electrodes for microelectronic applications is used industrially in high volume production, allowing use of different types of substrates such as silicon wafer $[9,10]$ and polymer [11]. This technique has been applied to silicon wafer based solar cells for a long time $[12,13]$; however, high temperature required for firing metal paste was not suitable for thin film solar cell process. Recently, low temperature metal paste has been developed, giving opportunity to use for thin film solar cells, which was practically used for electrode formation of thin film copper indium gallium diselenide (CIGS) solar cells [14].

In this work, we focused on the application of low cost screen printed Ag thick film as a back electrode of flexible thin 
film silicon solar cells and the evaluation of potential of the MOCVD ZnO/screen printed Ag back reflector. Additional processes to improve interface between $\mathrm{ZnO}$ and $\mathrm{Ag}$ layers and optimization of $\mathrm{n}$ layer for depositing upon textured surface $\mathrm{ZnO}$ layer also have been carried out.

\section{Experimental Details}

2.1. Preparation of Screen Printed Ag and ZnO Films. The Ag paste used in this study is a commercial low temperature paste specifically designed for solar cell applications. This Ag paste is normally employed to screen a front grid electrode of silicon wafer based and thin film solar cells, but we have examined new possibility to use it as a back electrode of flexible solar cell on polyimide (PI) substrate and to combine this printed layer with the MOCVD $\mathrm{ZnO}$ film to make an efficient back reflector. The Ag paste was screened on PI film by manual machine, fired in air atmosphere at various firing temperatures and firing times between $120-200^{\circ} \mathrm{C}$ and 10-60 min, respectively. Sheet resistance of the films was measured by using a four-point probe. The surface morphology was observed by scanning electron microscopy (SEM). Thickness was estimated by using step profilometer and its uniformity was determined by using the following equation: $(\operatorname{Max}-\operatorname{Min}) /(\operatorname{Max}+\operatorname{Min})$, where Max and Min are the maximum and minimum values of film thickness, respectively [15]. Utilizing the above formula, we calculated the uniformity of film thickness in $10 \times 10 \mathrm{~cm}^{2}$ substrate.

In this study, the $\mathrm{ZnO}$ films were deposited by two different techniques, MOCVD and DC-magnetron sputtering. The gas mixture of diethylzinc (DEZ) and water $\left(\mathrm{H}_{2} \mathrm{O}\right)$ was used as reactant gas and diborane $\left(\mathrm{B}_{2} \mathrm{H}_{6}\right)$ was employed as doping gas for depositing $\mathrm{ZnO}$ films by the MOCVD technique. The report on the properties of the MOCVD $\mathrm{ZnO}$ films in this study is published elsewhere [8]. On the other hand, the sputtered $\mathrm{ZnO}$ films were prepared by using $\mathrm{ZnO}$ target $(99.99 \%$ purity) doped with $2 \mathrm{wt} \%$ aluminum oxide $\left(\mathrm{Al}_{2} \mathrm{O}_{3}\right)$. These two different $\mathrm{ZnO}$ films were deposited subsequently onto the screen printed Ag layer; changes in the surface morphology of the samples have been particularly investigated.

2.2. Fabrication of $n-i-p$ Flexible Silicon Solar Cells. Single junction $\mathrm{n}-\mathrm{i}-\mathrm{p}$ amorphous silicon solar cells with a structure of $\mathrm{PI} /$ screen printed Ag/MOCVD $\mathrm{ZnO} / \mathrm{n} \mu \mathrm{c}-\mathrm{Si}: \mathrm{H} / \mathrm{i}$ a$\mathrm{Si}: \mathrm{H}(350 \mathrm{~nm}) / \mathrm{p}$ a-Si:H/sputtered $\mathrm{ZnO} / \mathrm{Ag}$ front grid were fabricated in order to estimate potential as a back electrode of the screen printed Ag thick film as well as performance of the MOCVD $\mathrm{ZnO} /$ printed Ag back reflector. Amorphous and microcrystalline silicon thin films were deposited by very high frequency plasma enhanced chemical vapor deposition (VHF PECVD) technique using a gas mixture of $\mathrm{SiH}_{4}$ and $\mathrm{H}_{2}$; phosphine $\left(\mathrm{PH}_{3}\right)$ and trimethylboron $(\mathrm{TMB})$ were employed as dopant sources for $\mathrm{n}$ and $\mathrm{p}$ type films, respectively. Cell active area was $1 \mathrm{~cm}^{2}$. The current-voltage $(I-V)$ characteristics of the solar cells have been investigated under standard testing conditions-AM1.5, $100 \mathrm{~mW} / \mathrm{cm}^{2}, 25^{\circ} \mathrm{C}$-in a Wacom solar simulator.
Improvement of contact interface of the MOCVD $\mathrm{ZnO} /$ screen printed Ag was carried out by an insertion of a thin sputtered $\mathrm{ZnO}$ layer. The thickness for this $\mathrm{ZnO}$ interface layer was varied from 0 to $210 \mathrm{~nm}$, while the thickness and conditions for other layers in the solar cells were kept as the same. Single junction n-i-p amorphous silicon solar cells with three different $n$ layers were prepared and comparatively characterized for the purpose of further optimizing the $\mathrm{n}$ layer. Firstly, the n $\mu \mathrm{c}-\mathrm{Si}: \mathrm{H}$ single layer with high conductivity was used and then double layer (seed layer + n $\mu \mathrm{c}-\mathrm{Si}: \mathrm{H})$ structure was developed. Finally, solar cells using the $\mathrm{n}$ type a-Si:H layer with various doping concentrations were prepared. In this study, the hydrogen dilution ratio $\mathrm{R}$, $\left[\mathrm{H}_{2}\right] /\left[\mathrm{SiH}_{4}\right]$, for $\mathrm{n}$ type $\mu \mathrm{c}-\mathrm{Si}: \mathrm{H}$ and a-Si:H films was not much different but the plasma power for the $\mathrm{n} \mu \mathrm{c}-\mathrm{Si}: \mathrm{H}$ was almost 2.7 times as high as that of the a-Si:H film deposition. Doping concentration ratio of the a-Si:H films was varied between 4500 and $12750 \mathrm{ppm}$. Note that the $\mathrm{n}$ layer was directly deposited on rough surface of the MOCVD $\mathrm{ZnO}$ film without any additional surface treatment process.

\section{Results and Discussions}

3.1. Properties of Screen Printed Ag Thick Films and $\mathrm{ZnO} /$ Screen Printed Ag Double Layer. Thickness of the screen printed Ag layer was about $25 \mu \mathrm{m}$ and its uniformity in $10 \times$ $10 \mathrm{~cm}^{2}$ substrate was determined to be approximately $\pm 8 \%$. The sheet resistance of the screen printed Ag thick films strongly depended on the firing temperature and firing time. It is found that the sheet resistance monotonously decreased with increasing firing temperature, and longer firing time seemed to be preferable since it also caused a reduction of sheet resistance. At $200^{\circ} \mathrm{C}$ firing temperature and 60-min firing time the screen printed Ag thick film showed the sheet resistance of about $12 \Omega$ /square. SEM results reveal that the screen printed Ag layer is porous film composed of interconnected oval-shaped particles, as shown in Figure 1(a), which is totally different from Figure 1(b) which shows the sputtered Ag films with high density and smooth surface. After the sputtered $\mathrm{ZnO}$ film was deposited upon the screen printed Ag layer, surface morphology of the sample did not show an obvious change. The oval-shaped particles were still clearly observed; however, the sheet resistance decreased to $10 \Omega /$ square and contact surface area of this layer seemed to increase due to the covering sputtered $\mathrm{ZnO}$ particles, as shown in Figure 1(c). On the other hand, when the MOCVD $\mathrm{ZnO}$ film was deposited subsequently over the screen printed Ag film, the fast-growing MOCVD $\mathrm{ZnO}$ film covered the whole surface of the printed Ag layer, showing pyramidlike surface morphology, as exhibited in Figure 1(d). The MOCVD $\mathrm{ZnO}$ film with high growth rate is thought to be more appropriate for the combination with the screen printed Ag back electrode than the sputtered $\mathrm{ZnO}$ film, since it can cover the whole surface of the porous layer, preventing Ag atom diffusion into thin film silicon layers when applied in cell structure. Moreover, its naturally textured surface gives advantage of light scattering function. 


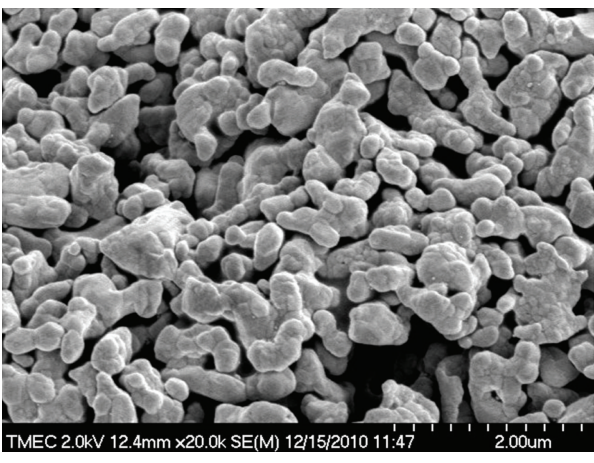

(a)

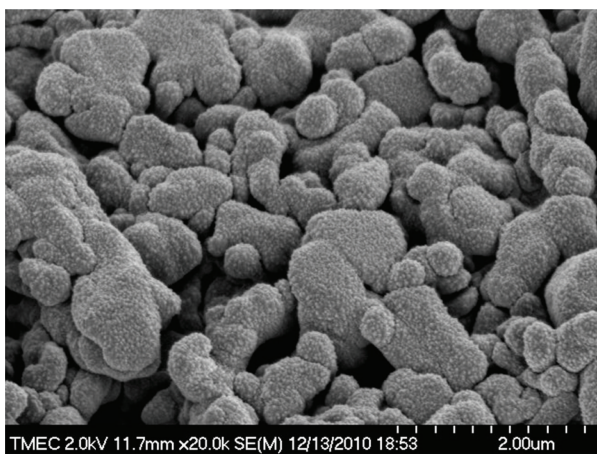

(c)

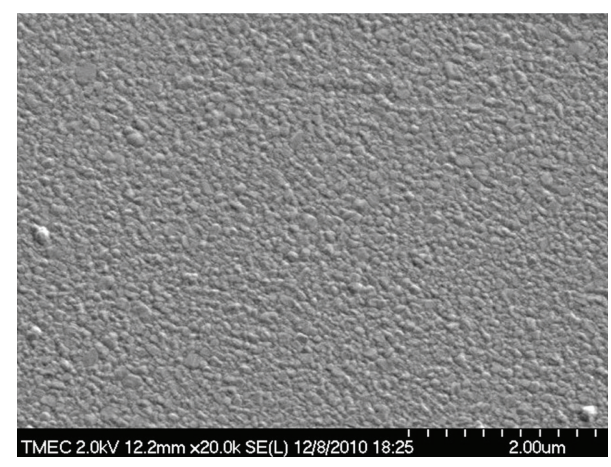

(b)

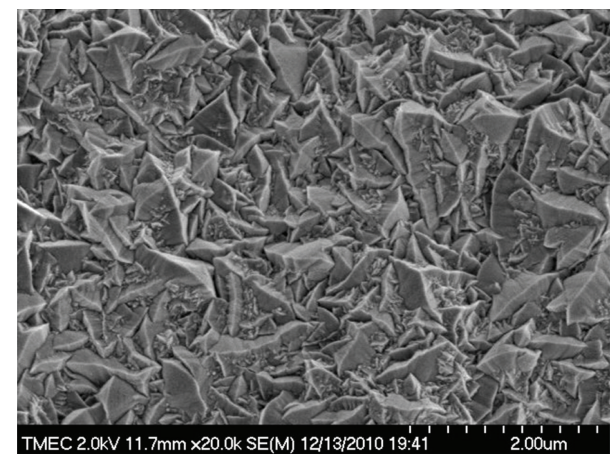

(d)

FIGURE 1: Surface morphology of (a) screen printed Ag on PI, (b) sputtered Ag on PI, (c) sputtered ZnO/screen printed Ag on PI, and (d) MOCVD ZnO/screen printed Ag on PI.

\subsection{Performance of Flexible Silicon Solar Cells Using Screen Printed Ag}

3.2.1. Benefit of the Sputtered $\mathrm{ZnO}$ Interface Layer. It was found that the solar cells using the screen printed $\mathrm{Ag}$ film as a back electrode showed poor $V_{\mathrm{oc}}$, only $0.60 \mathrm{~V}$, and FF as low as 0.33 . Shunt resistance $\left(R_{\mathrm{sh}}\right)$ was very low while series resistance $\left(R_{s}\right)$ was relatively high, indicating poor contact property of the cell. By attempting to improve screen printed $\mathrm{Ag} / \mathrm{MOCVD} \mathrm{ZnO}$ interface, we inserted a sputtered $\mathrm{ZnO}$ layer between these two layers with the aim of reducing voids. Figure 2 shows photovoltaic parameters of the solar cells as a function of the sputtered $\mathrm{ZnO}$ interface layer thickness. It is clearly shown that the $\mathrm{ZnO}$ interface layer is effective in improving performance of the solar cells; the $V_{\text {oc }}$ and FF dramatically increased. With increasing interface layer thickness the $R_{s}$ of the cell seemed to gradually decrease, while the $R_{\mathrm{sh}}$ showed a rapid increase when the interface layer was inserted; however, its variation was not dependent on the interface layer thickness, as shown in Figure 3. The enhancement in cell performance by inserting the $\mathrm{ZnO}$ interface layer was supposed to be attributed to increased contact surface area at the interface between the screen printed Ag and the MOCVD $\mathrm{ZnO}$ layers. As can be seen in Figure 1(c), sputtered $\mathrm{ZnO}$ film deposited on the screen printed Ag layer made a small texture over the oval-shaped particles, leading to an increase in contact surface area of the screen printed Ag layer. This additional layer allowed cell efficiency to reach $5.2 \%$ with $V_{\mathrm{oc}}=0.84 \mathrm{~V}, J_{\mathrm{sc}}=11.0 \mathrm{~mA} / \mathrm{cm}^{2}$ and $\mathrm{FF}=0.56$; however, all parameters were still low when compared to the conventional cells using the sputtered Ag electrode. Relatively low $R_{\mathrm{sh}}$ of the cells suggested shunt leak, which possibly occurred at the $\mathrm{n} \mu \mathrm{c}$-Si:H/MOCVD $\mathrm{ZnO}$ interface since microcrystalline films growing on textured surface tend to possess voids and nanocracks [5]. The film growth is known to depend strongly on the characteristics of the underlying layers or substrates; therefore, the MOCVD $\mathrm{ZnO}$ might be influenced by the surface morphology of the printed Ag layer. High-roughness Ag layer made the surface of the subsequent MOCVD $\mathrm{ZnO}$ layer become rougher, influencing a growth of the $n$ layer which eventually resulted in more serious shunt leak issue. Hence, further optimization of the $\mathrm{n}$ layer has been carried out, being described in the next subsection.

3.2.2. Optimization of $n$ Layer. Figure 4 shows photovoltaic characteristics of the $\mathrm{n}$-i-p flexible solar cells as a function of the $\mathrm{n} \mu \mathrm{c}$-Si:H thickness. Filled marks represent results of the solar cells without seed layer and blank marks stand for the solar cells using seed layer at the MOCVD $\mathrm{ZnO} / \mathrm{n} \mu \mathrm{c}-\mathrm{Si}: \mathrm{H}$ interface. Note that here seed layer is an undoped silicon thin film with the thickness of about $8 \mathrm{~nm}$ deposited under high hydrogen dilution condition. It was found that in the case of no seed layer the $V_{\mathrm{oc}}$ and FF were obviously low. Significant improvements of the $V_{\text {oc }}$ and FF were observed when the seed layer was inserted; however, the $J_{\mathrm{sc}}$ tended to decrease when this double layer, seed layer $+\mathrm{n} \mu \mathrm{c}$-Si:H layer, was used. The poor $V_{\mathrm{oc}}$ and FF of the cells were supposed to be due to voids 


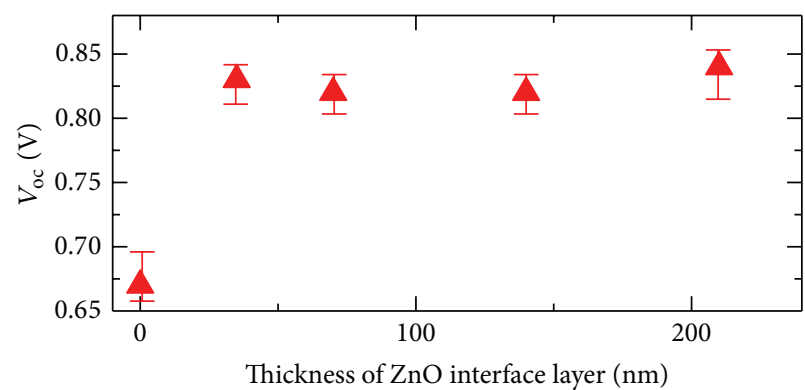

(a)

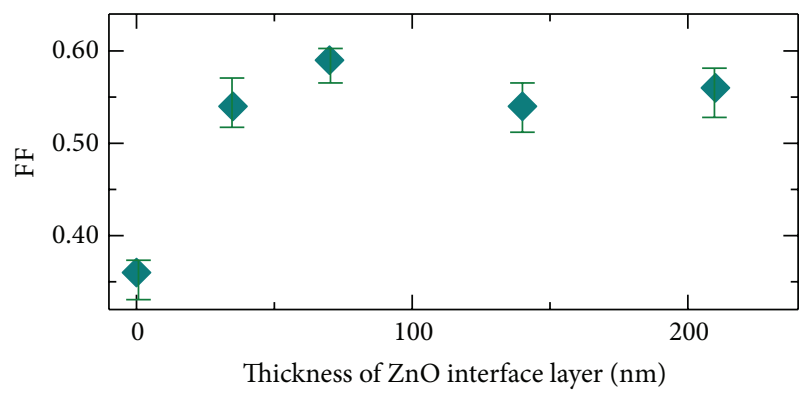

(c)

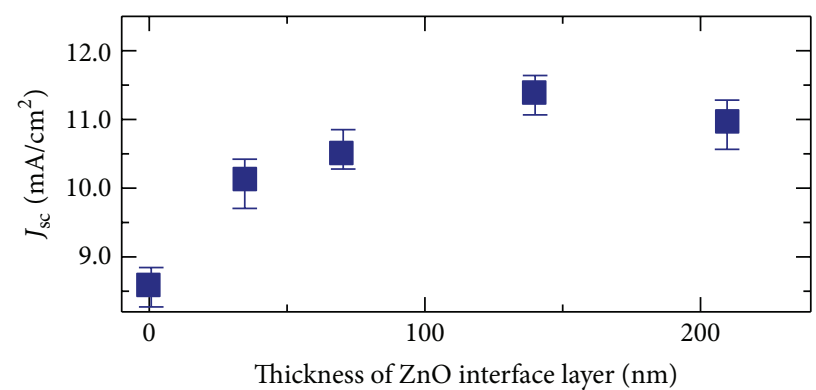

(b)

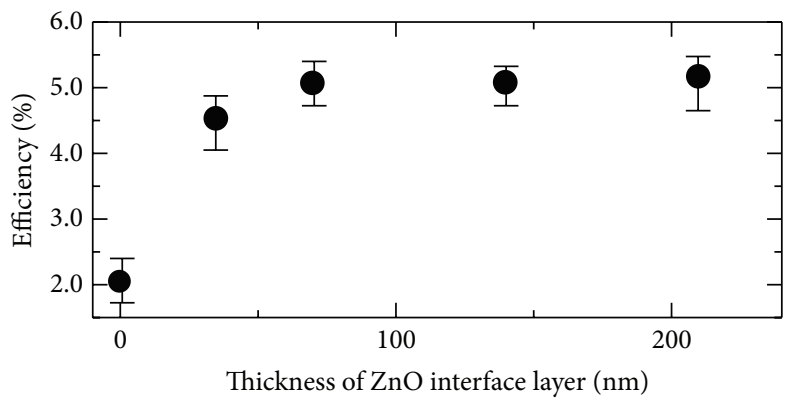

(d)

FIgURE 2: Photovoltaic parameters of flexible n-i-p amorphous silicon solar cells using the MOCVD ZnO/screen printed Ag back reflector as a function of thickness of the sputtered $\mathrm{ZnO}$ interface layer.

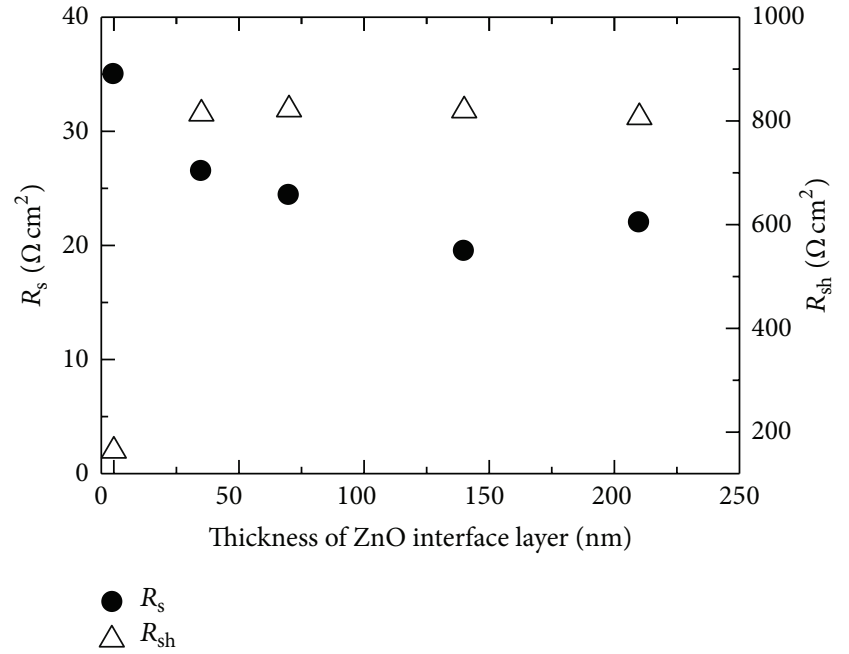

FIGURE 3: $R_{s}$ and $R_{\text {sh }}$ of flexible $n-i-p$ amorphous silicon solar cells using the MOCVD $\mathrm{ZnO} /$ screen printed Ag back reflector as a function of thickness of the $\mathrm{ZnO}$ interface layer.

and nanocracks in the $\mathrm{n} \mu \mathrm{c}$-Si:H layers directly grown on the textured $\mathrm{ZnO}$ layer. Although the $\mathrm{n} \mu \mathrm{c}$-Si:H films show high conductivity which preferably makes good contact, the shunt leak due to voids and nanocranks at the MOCVD $\mathrm{ZnO} / \mathrm{n} \mu \mathrm{c}-$ $\mathrm{Si}: \mathrm{H}$ interface is a serious issue. The presence of the buffer layer (seed layer) at the $\mathrm{ZnO} / \mathrm{n}$ layer interface which allowed the $\mathrm{n} \mu \mathrm{c}$-Si layer to grow on an amorphous phase at an initial step, effectively reducing a creation of voids and cracks at the $\mathrm{ZnO} / \mathrm{n}$ layer interface was thought to be a reason for cell improvement. Suppression of the shunt leak at the $\mathrm{ZnO} / \mathrm{n}$ layer interface, was verified by an increase in the $R_{\mathrm{sh}}$. Even though the insertion of the seed layer could improve the FF and $V_{\mathrm{oc}}$, trade-off against the $J_{\mathrm{sc}}$ should be concerned since increased film thickness is supposed to cause more optical loss, by which a decline of the $J_{\mathrm{sc}}$ is reflected.

Way to avoid $V_{\text {oc }}$ losses on textured surface which are compulsory for light trapping is to use n type a-Si:H layer, which is less sensitive to substrates morphology and materials. Therefore, we have applied the $\mathrm{n}$ type a-Si:H films with different doping concentration in the solar cells using the MOCVD ZnO/screen printed Ag back reflector. Seed layer was not used in this case. We have obtained relatively high $V_{\text {oc }}$ as well as high conversion efficiency at the doping concentration for n layer of about 8000 11200 ppm, where the films having relatively high conductivity with wide $E_{g}$ of $1.95 \mathrm{eV}$ and refractive index $(n)$ of 3.6 at the wavelength of $600 \mathrm{~nm}$ were obtained. Hence, we kept the doping concentration at $9750 \mathrm{ppm}$ and then further varied the thickness of the $\mathrm{n}$ a$\mathrm{Si}: \mathrm{H}$ layer. As shown in Figure 5, at the $\mathrm{n}$ a-Si:H thickness of about $24 \sim 27 \mathrm{~nm}$ solar cells showed relatively high $J_{\mathrm{sc}}$ and FF and also high cell conversion efficiency above 6\%. With further increasing $\mathrm{n}$ a-Si:H thickness, $\mathrm{FF}$ and $J_{\mathrm{sc}}$ tended to decrease, resulting in a decline of cell efficiency, which was probably due to increased $R_{s}$ and absorption loss inside the $\mathrm{n}$ layer. Using the a-Si:H films gives benefits of less sensitivity to the textured surface than the microcrystalline silicon film; moreover, the wider gap of $\mathrm{n}$ type a-Si:H films can reduce optical losses in the $\mathrm{n}$ layer and importantly the band diagram can be favorable for the $V_{\mathrm{oc}}$. The best initial cell efficiency of $6.2 \%$ with $V_{\mathrm{oc}}=0.86 \mathrm{~V}, J_{\mathrm{sc}}=12.4 \mathrm{~mA} / \mathrm{cm}^{2}$, 


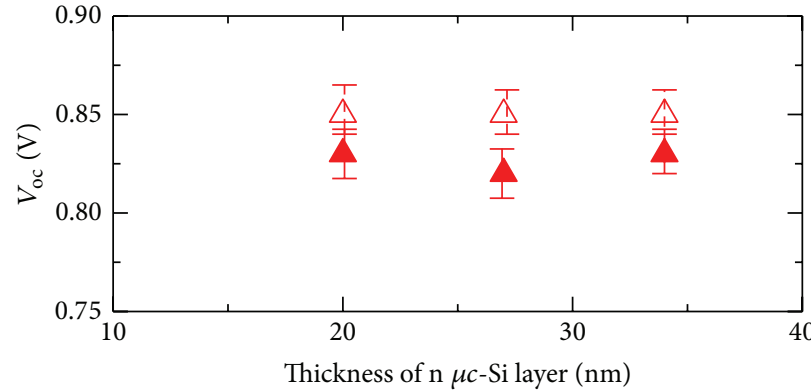

No seed layer

$\triangle$ With seed layer

(a)

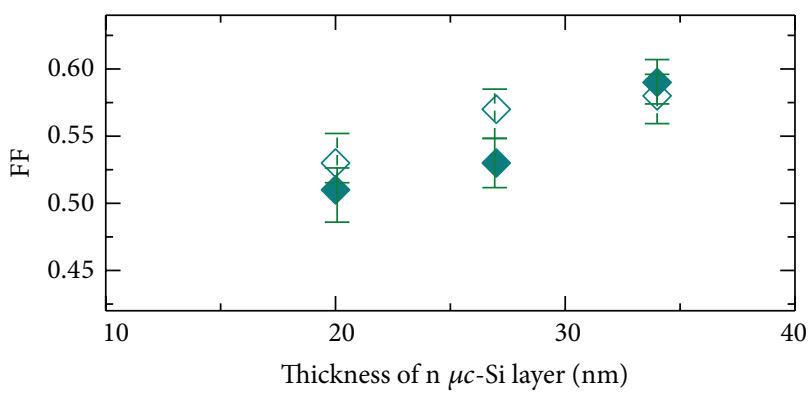

No seed layer

With seed layer

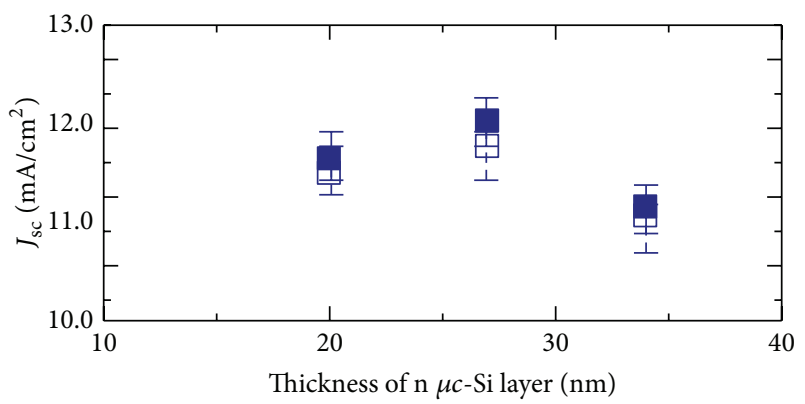

No seed layer

With seed layer

(b)

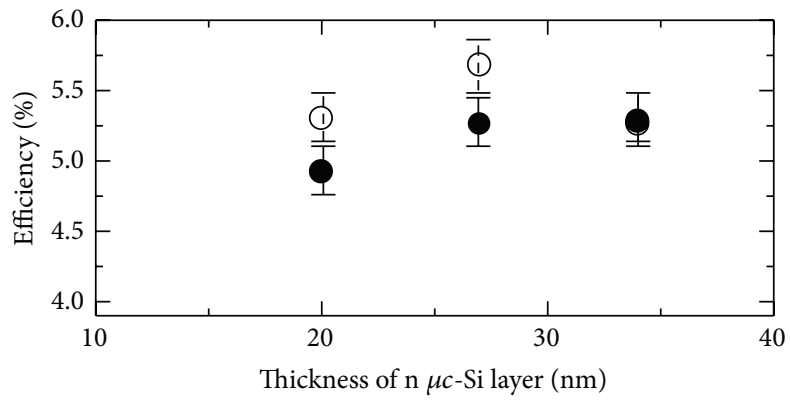

No seed layer

$\bigcirc$ With seed layer

(c)

(d)

FIGURE 4: Photovoltaic parameters of flexible n-i-p amorphous silicon solar cells with (blank mark) and without seed layer (filled marks) as a function of thickness of the $\mathrm{n} \mu \mathrm{c}-\mathrm{Si}: \mathrm{H}$ layer.

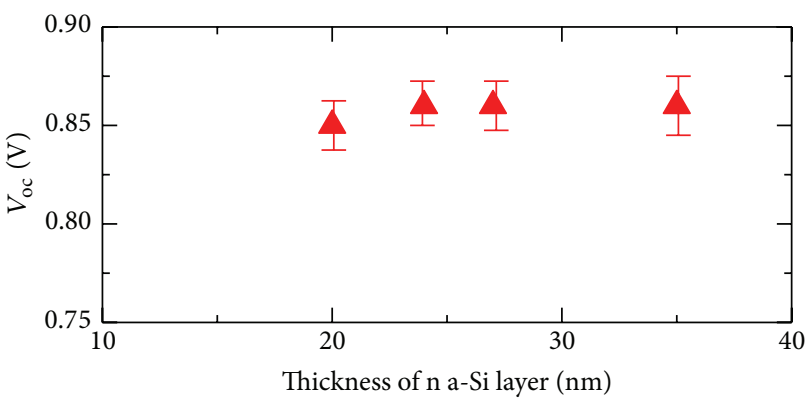

(a)

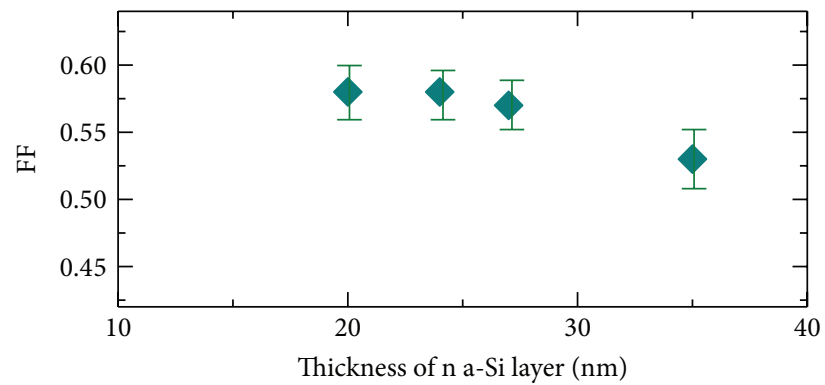

(c)

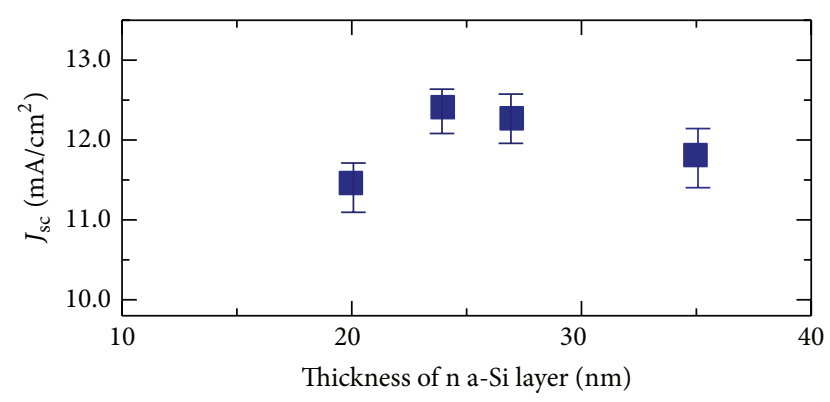

(b)

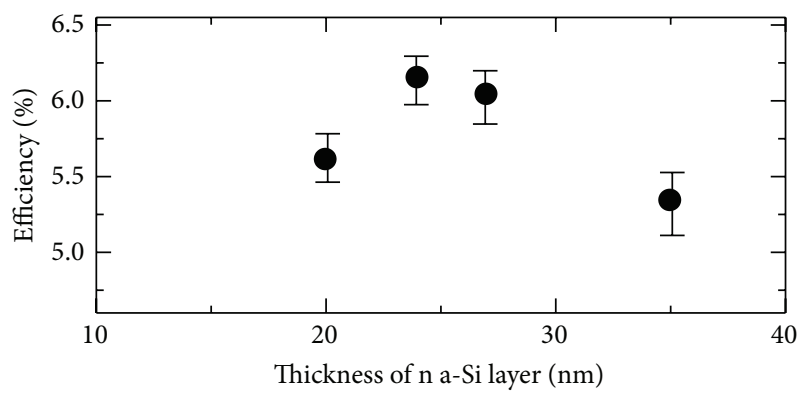

(d)

FIGURE 5: Photovoltaic parameters of flexible n-i-p amorphous silicon solar cells as a function of thickness of the $\mathrm{n}$ a-Si:H layer. 


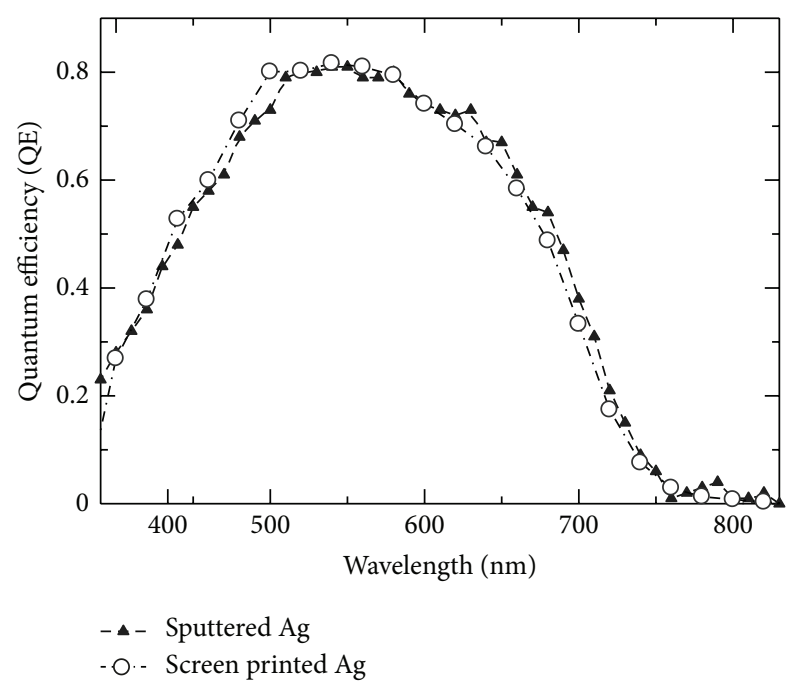

FIGURE 6: Quantum efficiency of flexible n-i-p amorphous silicon solar cell using sputtered Ag and screen printed Ag back electrode.

and $\mathrm{FF}=0.58$ was achieved for the cell using $\mathrm{n}$ type $\mathrm{a}-$ Si:H film, comparable to the cell with conventional sputtered Ag electrode [8]. Similar QE of these two cells, as shown in Figure 6, suggested almost identical performance of the MOCVD ZnO/sputtered Ag and the MOCVD ZnO/screen printed Ag back reflector, confirming possible opportunity to use low cost screen printed Ag for flexible thin film silicon solar cells.

\section{Summary}

We have prepared the Ag thick film by screen printing technique and developed the MOCVD $\mathrm{ZnO} /$ screen printed Ag back reflector for flexible n-i-p amorphous silicon solar cells.

The $\mathrm{ZnO}$ film deposited by MOCVD technique was chosen to use in combination with the screen printed Ag layer since its textured surface could enhance light scattering and also could quickly cover particles of the porous printed Ag layer owing to its high growth rate. The solar cells using the screen printed Ag showed low efficiency and FF as low as 0.33 in the beginning; however, the insertion of the sputtered $\mathrm{ZnO}$ interface layer at the MOCVD $\mathrm{ZnO} /$ screen printed $\mathrm{Ag}$ interface was effective in improving the FF as well as the cell efficiency. The $\mathrm{n}$ a-Si:H film was preferable for the deposition on the rough surface of the MOCVD $\mathrm{ZnO}$ film than the $\mu \mathrm{c}-\mathrm{Si}: \mathrm{H}$ film due to its less sensitivity to textured surface, and this allowed further improvements in the $V_{\mathrm{oc}}$ and FF. The efficiency and QE results of the cell using the MOCVD $\mathrm{ZnO} /$ screen printed $\mathrm{Ag}$ back reflector were comparable to the conventional cell with the MOCVD $\mathrm{ZnO} /$ sputtered $\mathrm{Ag}$, demonstrating efficient performance of the proposed MOCVD $\mathrm{ZnO} /$ screen printed $\mathrm{Ag}$ back reflector as well as possible opportunity to apply low cost screen printed film for flexible thin film silicon solar cells.

\section{Conflict of Interests}

The authors declare that there is no conflict of interests regarding the publication of this paper.

\section{Acknowledgment}

This work was supported by Cluster and Program Management Office (CPMO) of NSTDA, Thailand (P-11-30005).

\section{References}

[1] Y. Ichikawa, T. Yoshida, T. Hama, H. Sakai, and K. Harashima, "Production technology for amorphous silicon-based flexible solar cells," Solar Energy Materials and Solar Cells, vol. 66, no. 1-4, pp. 107-115, 2001.

[2] H. Mase, M. Kondo, and A. Matsuda, "Microcrystalline silicon solar cells fabricated on polymer substrate," Solar Energy Materials and Solar Cells, vol. 74, no. 1-4, pp. 547-552, 2002.

[3] M. N. van den Donker, A. Gordijn, H. Stiebig et al., "Flexible amorphous and microcrystalline silicon tandem solar modules in the temporary superstrate concept," Solar Energy Materials and Solar Cells, vol. 91, no. 7, pp. 572-580, 2007.

[4] Y. Ishikawa and M. B. Schubert, "Flexible protocrystalline silicon solar cells with amorphous buffer layer," Japanese Journal of Applied Physics A, vol. 45, no. 9, pp. 6812-6822, 2006.

[5] T. Söderström, F.-J. Haug, V. Terrazzoni-Daudrix, and C. Ballif, "Optimization of amorphous silicon thin film solar cells for flexible photovoltaics," Journal of Applied Physics, vol. 103, no. 11, Article ID 114509, 2008.

[6] J. K. Rath, M. Brinza, Y. Liu, A. Borreman, and R. E. I. Schropp, "Fabrication of thin film silicon solar cells on plastic substrate by very high frequency PECVD," Solar Energy Materials and Solar Cells, vol. 94, no. 9, pp. 1534-1541, 2010.

[7] K. Tao, D. Zhang, L. Wang et al., "Development of textured back reflector for n-i-p flexible silicon thin film solar cells," Solar Energy Materials and Solar Cells, vol. 94, no. 5, pp. 709-714, 2010.

[8] A. Limmanee, P. Krudtad, S. Songtrai, C. Piromjit, J. Sritharathikhun, and K. Sriprapha, "ZnO back reflector prepared by MOCVD technique for flexible solar cell applications," Current Applied Physics, vol. 11, no. 1, pp. S206-S209, 2011.

[9] H. D. Goldberg, R. B. Brown, D. P. Liu, and M. E. Meyerhoff, "Screen printing: a technology for the batch fabrication of integrated chemical-sensor arrays," Sensors and Actuators B, vol. 21, no. 3, pp. 171-183, 1994.

[10] D. Vincenzi, M. A. Butturi, V. Guidi et al., "Development of a low-power thick-film gas sensor deposited by screen-printing technique onto a micromachined hotplate," Sensors and Actuators $B$, vol. 77, no. 1-2, pp. 95-99, 2001.

[11] S. Merilampi, T. Laine-Ma, and P. Ruuskanen, "The characterization of electrically conductive silver ink patterns on flexible substrates," Microelectronics Reliability, vol. 49, no. 7, pp. 782790, 2009.

[12] M. Böhm, E. Urbanski, A. E. Delahoy, and Z. Kiss, "Screenprinted particulate silicon devices for photovoltaic applications," Solar Cells, vol. 20, no. 2, pp. 155-166, 1987.

[13] D. Erath, A. Filipović, M. Retzlaff et al., "Advanced screen printing technique for high definition front side metallization of crystalline silicon solar cells," Solar Energy Materials and Solar Cells, vol. 94, no. 1, pp. 57-61, 2010. 
[14] D. C. Nguyen, K. Takehara, T. Ryo, and S. Ito, "Back contact materials for superstrate $\mathrm{CuInS}_{2}$ solar cells," Energy Procedia, vol. 10, pp. 49-54, 2011.

[15] K. Hieber, H. Körner, and H. Treichel, "Chemical vapour deposition of oxide and metal films for VLSI applications," Thin Solid Films, vol. 181, no. 1-2, pp. 75-84, 1989. 

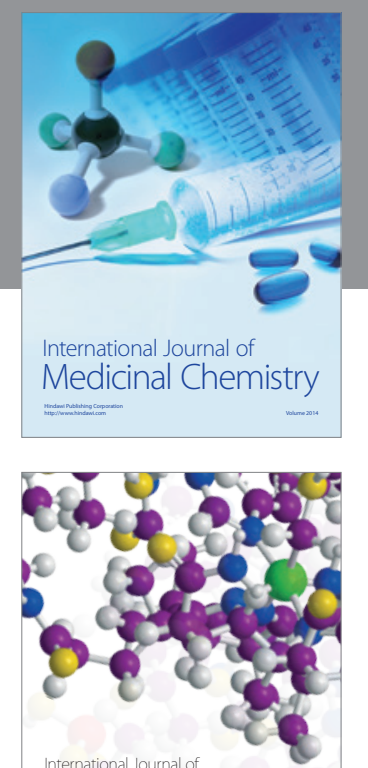

\section{Carbohydrate} Chemistry

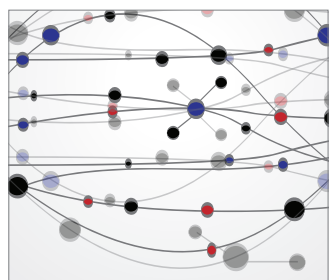

The Scientific World Journal
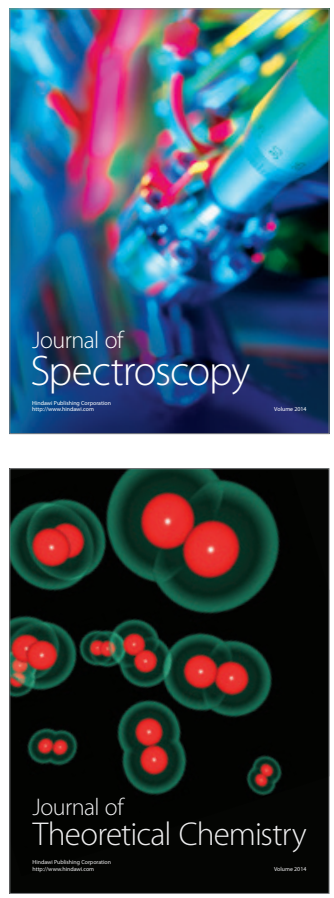
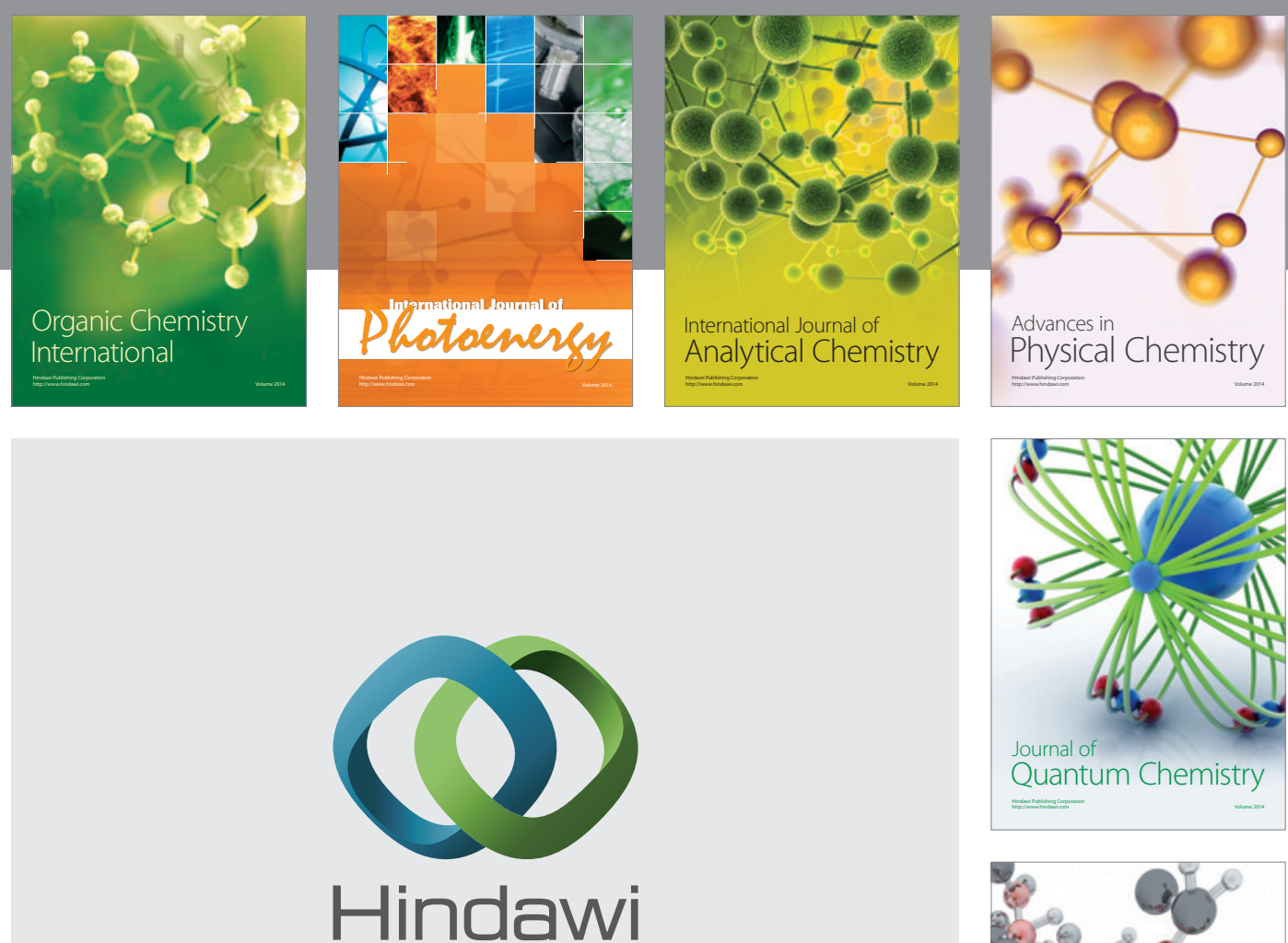

Submit your manuscripts at

http://www.hindawi.com

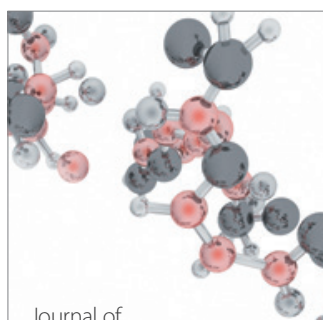

Analytical Methods

in Chemistry

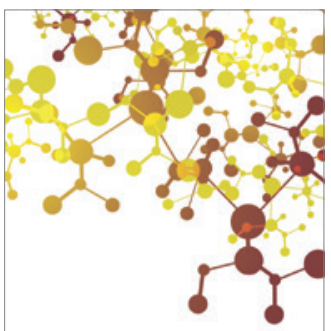

Journal of

Applied Chemistry

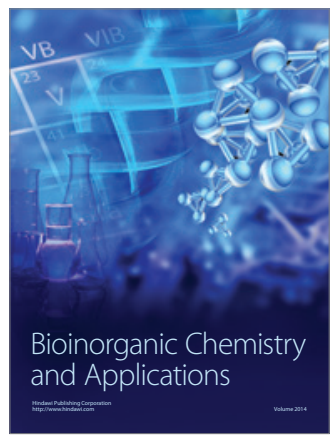

Inorganic Chemistry
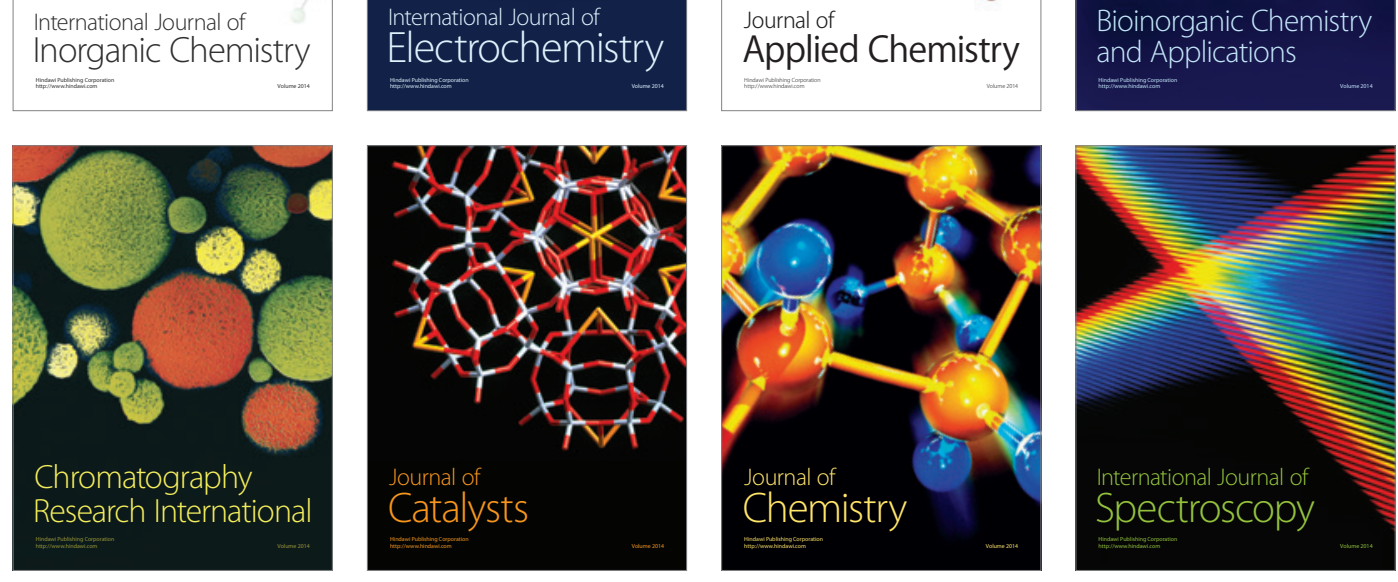